\title{
UNPACKING PEDAGOGICAL CONTENT KNOWLEDGE AND CONTENT KNOWLEDGE: ASSESSING TECHNICAL VOCATIONAL EDUCATION TRAINING COLLEGE LECTURERS' PEDAGOGICAL CONTENT KNOWLEDGE ON TOPIC SPECIFIC KNOWLEDGE
}

\author{
Molefi Motsoeneng ${ }^{1}$ \\ ${ }^{1}$ Central University of Technology, Faculty of Humanities, School of Professional Studies, Free \\ State, South Africa, smotsoen@cut.ac.za
}

\begin{abstract}
This paper focuses on the nature of entrepreneurship education with particular regard to the pedagogical content knowledge and content knowledge of Technical Vocational Education and Training College lecturers in their teaching of entrepreneurship. The paper operationalises the participatory action research approach, in which a team is assembled to empower co-reseachers to find the solutions to their problems. The team consisted of two lecturers, two students, a learning facilitator, local entrepreneurs, and a parent. The results reveal that lecturers do not possess a deep knowledge of both pedagogical content knowledge, content knowledge and that the pedagogy used for teaching students is mostly outdated. Lecturers do not address students' valid misconceptions of entrepreneurship . During lessons, they seem mostly unable to elucidate student entrepreneurship errors and so cannot present complete solutions. A deep understanding of entrepreneurship theory would thus seem to be a precondition for developing lecturers' pedagogical content knowledge in the teaching of entrepreneurship education concepts.
\end{abstract}

Keywords: Pedagogical Content knowledge; content knowledge; Entrepreneurship Education; Technical Vocational Education and Training College; Participatory Action Research

\section{INTRODUCTION}

The aim of this paper is to unpack the pedagogical content knowledge (PCK) and content knowledge (CK) of lecturers in technical vocational education training colleges (TVET) with regard to their topic specific knowledge of entrepreneurship education (EE). A teacher's knowledge and understanding of the content to be taught is a prerequisite of effective teaching (Janík, Najvar, Slavík \& Trna, 2009). PCK is the "knowledge to make subject matter accessible to students" (Kleickmann et al., 2013, p. 91) and is understood as a combination of "content and pedagogy that is uniquely the province of teachers, their own special form of professional understanding" (Keller, Neumann, \& Fischer, p. 2017). Lecturers who possess poor CK tend to transfer misconceptions to their students, as opposed to those who are knowledgeable who consequently utilise students' prior knowledge and exclude unnecessary concepts from their lessons. Furthermore, 
lecturers who posses poor CK tend to struggle with classroom control, are unable to detect students' learning difficulties, and are obsessed with teaching that lacks objectives (Zaman, \& Ahangari, 2016).

Previous studies have reported that lecturers have poor understanding of EE constructs (Motsoeneng \& Mahlomaholo,2015; Motsoeneng \& Qhosola, 2021). They themselves have misconceptions about different concepts and tend to transfer these to students during teaching (Motsoeneng \& Qhosola, 2021). Students find it difficult to understand the abstract concepts of EE, which is often the result of lecturers who lack practical experience of the running of an enterprise (Motsoeneng, \& Mahlomaholo, 2015). In order to repond to students' misconceptions, lecturers should also take into account students' prior learning, thus enabling students to build on knowledge they have previously learned.

Knowledge of student misconceptions by the lecturer is vital to overall lecturer teaching (Chen, Sonnert, Sadler, Sasselov, \& Fredericks, 2019). They are considered the root problem of students' poor performance in EE (Aygor \& Ozdag, 2012.). A lecturer who possesses deep CK and PCK will be able to deal effectively with students' difficulties (Depaepe, et al., 2015). To overcome the students' misconceptions, a deep knowledge of PCK and CK is important for effective teaching of EE (Fatokun, 2016). Thus, knowledge can assist lecturers to anticipate students' learning difficulties and provide an appropriate explanation to deal with them effectively. Before teaching can take place, lecturers should identify students' misconceptions and incorporate them into their lessons. In this way, they can be attended to early in conceptions (Wong \& Sulaiman, 2008). Limited CK and PCK by the lecturer, as articulated by Motsoeneng \& Mahlomaholo (2015), affect the lecturer's ability to comprehend students' preconceptions and misconceptions.

Lessons should be so prepared as to effectively correct misconceptions which, if not corrected, will hamper students' ability to learn. Awareness of students' errors and misconceptions in the process of learning is considered to be a basis for uncovering their conceptions, ways of thinking, and learning difficulties (Sisman \& Aksu, 2016). Erroneous responses to a question (Hadjidemetriou \& Williams, 2002, p. 69) have their source in lack of comprehension of basic facts, concepts, and skills (Legutko, 2008).

Such difficulties, including PCK, call for a different approach to enhance the PCK of lecturers. Pinamang and Penrose (2017) suggest the approach of striving to make entrepreneurship pedagogy practical by providing more opportunities for lecturers to practise more of what they are teaching at TVET Colleges.

\section{METHODOLOGY}

Participatory Action Research (PAR) provides a methodological framework and the ideological standards for rigour in the research that contributes both to knowledge generation, as well as social action such as community mobilization. PAR is described by researchers as a more collaborative and democratic approach to research built on communication, negotiation, observation, reflection and analysis between scientists and non-scientists sharing local knowledge and expertise (Heidi, Ballard \& Belsky,. 2010).

A team of co-researchers was formed to respond to the more practical approach of tackling the lack of PCK in lecturers. The team consisted of a Learning Facilitator, a Head of Department, two lecturers, a student, and a local entrepreneur. PAR aims at affording the opportunity for co-researchers to co-produce knowledge that will lead to sustainable solutions to the teaching of EE (Khatri \& Ozano, 2017). A fundamental issue within PAR is the balance of power and PAR recognises that the co-researchers bring diverse skill and knowledge to the benefit of the project (Karnieli-Miller, Strier, \& Pessach 2009).

\section{FINDINGS AND DISCUSSION}

\subsection{Poor Pedagogical Content Knowledge}

Rhoads \& Weber (2016) state that lecturers must demonstrate that they know the content and apply relevant policies for student to interact with. CK is a core competence for an EE lecturer, who should have the ability to reconstruct the scientific knowledge needs to be outlined for teaching purposes (Nousiainen, $2017 \mathrm{p}, 214$ ). One of the most well-established research findings is that lecturers' knowledge of students' reasoning is an essential component for student learning (Mahera, Sigleyb, Sullivanc, \& Wilkinsond, 2018 p 73). The majority of TVET college lecturers do not have deep CK knowledge of EE concepts. This is a result of poor training received from universities which has insufficiently prepared them to teach EE effectively (DBE, 2009), thus not enabling them to achieve expected education outcomes (DBE, 2009). The DoE (2004) asserts that, without appropriate training at tertiary level, lecturers will carry forward the poor teaching practices they brought from school to their own teaching.

Lecturers' inability to anticipate, as well as their poor knowledge of PCK, was evident during a lesson presented by Mr Mofokeng: 
Mr Mofokeng: A more common form of business is sole trader, a company is very complicated for an average man to run it.

Disuseng: What is complicated in company, sir, because you run it like any other business. With limited liability sir, as stated in a textbook. By the way what is limited liability, sir?

The concept of limited liability is not well understood by both the lecturer and the student. The poor knowledge of the lecturer is a deficiency which disables him from explaining the concept to the student. In addition to this, the student's knowledge involves a misconception of limited liablity as a way to run away from company debts. The lecturer with limited CK may even reinforce the misconceptions of the student. In this case, the lecturer failed to identify the student's prior knowledge on the topic, which could have been used as the starting point in addressing the misconceptions. Thus, students are unable to connect new knowledge with their prior knowledge of the topic taught.

The manner in which the lesson was presented did not create an encouraging platform for students to seek deeper understanding which would allow students to engage in the topic. The lesson was facilitated in an abstract manner which did not give students a chance to comprehend the concepts. Social constructivist learning theory, which could have helped students create their own meaning rather than being filled with incorrect information, was ignored. The lecturer presented the lesson without involving the students or ascertaining their prior knowledge on the topic, for example, of window of opportunity. The students sat passively like empty vessels waiting to be filled with knowledge. Their responses suggested that they were simply a group of demotivated students.

However, the lecturer could have created an environment conducive for students to engage with the topic which could have enabled them to learn from each other. The lecturer could have acted as the facilitator for the discussion. In the process, the lecturer could have identified and assessed the students' prior knowledge. In doing so, the lecturer would have "evaluated students' prior knowledge and identified and clarified any shortcomings and knowledge gaps” (DoE, 2011: 10).

A lecturer's limited PCK denies him the opportunity to identify students' misconceptions. The lecturer who does not understand students' misconceptions does not explain effectively so students do not enjoy the lesson. The students become disruptive and the lecturer is unable to control the class. In the worst case scenario, the students do not attend the class.

\subsection{Sufficient Pedagogical Content Knowledge among Lecturers}

The PCK construct has been widely used because it accurately describes teacher's knowledge. PCK helps teachers incorporate the nature of EE which is relevant to teaching-learning actions. This is carried out by means of the various forms of wisdom and practice which constitute the transformation of subject matter knowledge (SMK) that can be effectively used in professional development (Botha \& Reddy, 2011). The lecturer's way of transfering EE knowledge to students with understandable technique is the core of PCK (Lee, 2010). The lecturer's mastery of the lesson or EE content is obviously important for success. A lecturer cannot be expected to explain a mathematic concept, if he does not have a complete comprehension of that concept (Ilyay, Budayasa \& Juniati, 2016). The lecturer should have a well-developed understanding of the knowledge appropriate to the specialisation (DHET 2011:49). The DBE and DHET (2011:4) maintain that despite the fact that "a wide assortment of components connect to effect on the nature of the training framework in South Africa, instructors' poor topic learning and academic substance information are significant givers". The Integrated Strategic Planning Framework for Teacher Education and Development in South Africa 2011-2025 emphasises instructor readiness which, in turn, explicitly highlights the topic of learning and academic substance information (DBE and DHET, 2011). Lecturers should be well-grounded in the information, abilities, values, standards, techniques, and methods significant to the stage, subject, control or practice.

After the team met and discussed strategies on how best to improve the lesson on forms of ownership, Mr Mofokeng presented the idea as follows:

Mr Mofokeng: A sole proprietor is more simple form of ownership, no formal registration unlike a company. The assets of owner are not separated from business, thus the debts of busness legally are owners's debts.

Sello: What about a company, sir?

Mr Mofokeg: a company is owned by shareholders, a legal person can be sued and sue as well. When the compny goes down the shareholders are not liable. They cannot be called to settle the company 
debts.

The lecturer throughout has anticipated the students' response and worked out his lesson to continously check student understanding as he explains forms of ownership. The lecturer has successfully dealt with conceptions and misconceptions throughout the lesson. The deep PCK of the lecturer was displayed when he was able answer students' questions appropriately. A deep PCK was key in assisting the lecturer to anticipate students' difficulties and address them. This was achieved as a result of practical experience.

\subsection{Conditions Necessary to Enhance Pedagogical Content Knowledge among Lecturers}

The possession of PCK is a pre-requisite for the lecturer to address students' misconceptions

(Neumann, Kind \& Harms, 2018:3) and amounts to the ability to identify the students' misconceptions, using effective strategies to help students to avoid them (Mishiwo, Sedega, Anane, \& Kofi, 2017). The lecturer has to demonstrate an ability that ensures that the thinking of students is not limited to what they are taught. This highlights the importance of the lecturer working collaboratively with other EE lecturers and experts in education. The conditions prevailing in such classes would allow students to discover interesting and strange things and amazing EE concepts, concepts which would provoke still further thinking of the students.

In a class conducted by Mr Mofokeng, this is what transpired:

Mr Mofokeng: A most appropriate form is sole proprietor.

Mpuse: What about the company Sir. I will buy into it because has limited liability.

Mr Mofokeng: A company requires lot of formalities, stay away from it.

The lecturer tried very hard to discourage a company as an ideal form of business. The discussion that ensued demonstrated the students' poor understanding which resulted in errors and misconceptions which would have to be addressed by the lecturer. Such a strategy results in students not carrying their misconceptions to the next level of their study. The lecturer was able to expand students' thinking through proper probing.

\subsection{Threats towards Pedagogical Content Knowledge}

The training the lecturer has undergone may threaten implementation of the framework. Recognising a misconception takes lecturers experienced in the ability to recognise and address students' errors. However, some lecturers commit the same mistakes as students (Şimşek \& Boz, 2016). The lecturer who possesses poor CK poses the threat of tending to transfer incorrect information to the students (Wooditch, Rice, Peake \& Rubenstein, 2018). Poor CK and PCK will result in a lecturer having difficuly in teaching EE and the ability to enhance students' understanding will not happen (Tseng, 2016). After researching PCK, an EE lecturer found that "despite having a strong background in EE content, many of the lecturers were unable to apply that content knowledge and related skills to their classroom instruction" (Rice \& Kitchel, 2016:87).

Mr Mofokeng's class suggests that poor CK and PCK can derail effective teaching of EE. The students are taught the concepts incorrectly by a lecturer who has poor CK and PCK. If the lecturer had had enough PCK, he could have dealt with the student's misconceptions and inaccurate information about idea and opportunity, whereas he is unable to deal with students' difficulties and enhance students' understanding.

\section{EVIDENCE}

\subsection{Improved Content knowledge and Pedagogical content knowledge}

Previous studies demonstrate that the approach of PAR has improved lecturers' PCK (Motsoeneng \& Mahlomaholo, 2015; Motsoeneng \& Qhosola, 2021). Such studies have also gained knowledge of the difficulties that students' experience regarding EE, as well as the tendency to incorrectly generalise when dealing with EE topics. These are the motivating factors for designing a framework for the PCK of TVET College lecturers. The basis is "CK is a necessary condition for development" of PCK (Oppermann, Anders \& Hachfeld, 2016:181). PCK is not subject matter knowledge, it rather embraces the understanding of learning difficulties and student conceptions. It has to do with a lecturer who cannot transform the topic so as to encourage students. PCK has been alluded to as a lecturers' elucidations and changes in the information on a topic which encourage students' learning (Kola \& Sunday, 2015:82).

The lecturer's deep understanding of PCK cannot be over-estimated. SMK is the key accompaniment of the knowledge of students' conceptions and problems (Widodo, 2017:2) and also students' understanding and 
errors in entrepreneurship. A deep CK would give a lecturer the edge in easily reflecting on student understanding (Maryani, 2015:39).

\section{CONCLUSION}

The use of a team supporting the lecturers makes it easier for them to improve their pedagogy. PAR, as applied in education, can assist in improving the PCK and CK of TVET college lecturers. The paper has successfully established that CK and PCK of lecturers can be improved by the support of people from diverse backgrounds who are concerned by students' poor results. They were able to bring their expertise to empower the lecturers. The members of a team also benefit form the experience and diverse background of other team members.

\section{REFERENCE LIST}

Aygor, N. and H. Ozdag. (2012).Misconceptions in linear algebra: The case of undergraduate students. Procedia - Social and Behavioral Sciences, 46: 2989-2994.

Botha, M.L., \& Reddy, C.P.S. (2011). In-service Teachers' Perspectives of Pre-Service Teachers' Knowledge Domains in Science. South African Journal of Education, 31, 257-274.

Chen, C., Sonnert, G. Sadler, P.M., Sasselov, D. \& Fredericks C. (2019). The impact of student misconceptions on student persistence in a MOOC. Journal of Research in Science Teaching, 57(6): 879-910.

Depaepe, F., Torbeyns, J., Vermeersch, N., Janssens, D., Janssen, R., Kelchtermans, G., Verschaffel, L. \& Van Dooren, W. (2015).. Teachers' content and pedagogical content knowledge on rational numbers: A comparison of prospective elementary and lower secondary school teachers. Teaching and Teacher Education 47: 82-92

Department of Higher Education and Training (DHET). (2011). Minimum requirements for teacher education qualifications. Pretoria.

Department of Education (DoE). (2004). Qualitative overview of the Further Educationa and Training Sector: A Sector in Transition. Pretoria: Department of Education

Department of Basic Education (DBE). (2009). National examinations and assessment: report on the national senior certificate examination results, Part 2. Pretoria: Department of Basic Education (DBE).

Fatokun, K.V.F. (2016). Instructional misconceptions of prospective chemistry teachers in chemical bonding. International Journal of Science and Technology Education Research, 7(2): 1824.DOI:10.5897/IJSTER2016.0357

Hadjidemetriou, C. \&. Williams, J. S. (2002). "Children's graphical conceptions." Research in Mathematics Education 4: 69-87.

Heidi L. Ballard \& Belsky, J.M. (2010) Participatory action research and environmental learning: implications for resilient forests and communities. Environmental Education Research, 16:5-6: 611-627, DOI: $10.1080 / 13504622.2010 .505440$

http://eprints.utm.my/7669/

Ilyay, M., Budayasa, I. B. \& Juniati, D.(2016).Pedagogical Content Knowledge: Teacher's Knowledge of Students in Learning Mathematics on Limit of Function Subject. Journal of Physics: Conference Series, Volume 954, Joint Workshop of KO2PI \& 2nd International Conference on Mathematics, Science, Technology, Education, and their Applications (2nd ICMSTEA) 3-4 October 2016, Makassar, Indonesia

Janík, T. , Najvar , P., Slavík, J. \& Trna, J. (2009). On The Dynamic Nature Of Physics Teachers' Pedagogical Content Knowledge. Orbis Scholae, 3 (2): 47-62,

Karnieli-Miller, O., Strier, R., \& Pessach, L. (2009). Power Relations in Qualitative Research. Qual Health Res, 19 (2):279-89. doi: 10.1177/1049732308329306.

Keller, M. M., Neumann, K., \& Fischer, H. E. (2017). The impact of physics teachers' pedagogical content 
knowledge and motivation on students' achievement and interest. Journal of Research in Science Teaching, 54(5), 586-614.

Khatri, R.J. \& Ozano, K.A. (2017) Reflexivity, Positionality and Power in Cross-Cultural Participatory Action Research with Research Assistants in Rural Cambodia. Educational Action Research, 26:2, 190-204. DOI: 10.1080/09650792.2017.1331860

Kleickmann, T., Richter, D., Kunter, M., Elsner, J., Besser, M., Krauss, S., \& Baumert, J. (2013). Teachers' content knowledge and pedagogical content knowledge: The role of structural differences in teacher education. Journal of Teacher Education, 64(1), 90-106. doi: 10.1177/ 0022487112460398.

Lee, J. (2010). Exploring Kindergarten Teachers' Pedagogical Content Knowledge of Mathematics: Department of Curriculum and Instruction-EC4, College of Education and Health Profesional, University of Texas at Arlington, Science Hall.

Legutko, M. (2008). An analysis of Students' Mathematical Errors in The Education-Research Process. In B. Czarnocha (Ed.), Handbook of mathematics teaching research: Teaching experiment -a tool for teacherresearchers (pp. 141-154). Poland: Drukarnia Cyfrowa Kserkop

Maher, C.A.,Sigley, R.,Sullivan, P.. \& Wilkinson, L.C.2018. An international perspective on knowledge in teaching mathematics. The Journal of Mathematical, 51: 71. 79.https://doi.org/10.1016/j.jmathb.2018.05.002 Mishiwo, M., Sedega, B.C., Anane, B.C. \& Kofi, G.A. (2017). Pre-Service Teachers' Use of Pedagogical Content Knowledge in Teaching and Learning Mathematics at Basic Seven in Akatsi District, Ghana.British Journal of Education, 5(2):65-76.

Maryani, I.2015. Correlation between Teacher's PCK (Pedagogical Content Knowledge) and Student's Motivation in Primary School. International Journal of Evaluation and Research in Education (IJERE), 4(1): 38 44.

Motsoeneng, M. \& Qhosola, M.R. (2021). Towards a framework of pedagogical content knowledge in Entrepreneurship Education for Technical Vocational Education and Training College lecturers. Technium Social science Journal, 25:81-92.

Motsoeneng, M. \& Mahlomaholo, S. (2015). Entrepreneurship Education for Further Education and Training College Lecturers. ICIE 2015 3rd International Conference on innovation and Entrepreneurship: ICIE 2015, 120, 2015.

Neumann, K., Kind, V. \& Harms, U. (2018).Probing the Amalgam: The Relationship between Science Teachers' Content, Pedagogical and Pedagogical Content Knowledge. International Journal of Science Education, 41(7): 847-861.

Nousiainen, M. (2017). Organization of Physics Content Knowledge for Teaching Purposes: from Knowledge Justification Schemes to Didactical Schemes. European Journal of Science and Mathematics Education, 5(2): 210-209.

Oppermann, E., Anders, Y. \& Hachfeld, A.2016.The Influence of Preschool Teachers' Content Knowledge and Mathematical Ability Beliefs on Their Sensitivity to Mathematics in Children's Play. Teaching and Teacher Education, 58:174-184.

Pinamang, I. \& Penrose, O.C. (2017). Pre-service teachers' content knowledge and pedagogical content knowledge in teaching geometric transformation. African Journal of Educational Studies in Mathematics and Sciences, 13:63-70.

Rhoads, K. \& Weber, K. (2016). Exemplary High School Mathematics Teachers' Reflections on Teaching: A Situated Cognition Perspective on Content Knowledge. International Journal of Educational Research, 78: $1-12$.

Rice, A.H. \& Kitchel, T. (2016). Influence of Knowledge of Content and Students on Beginning Agriculture Teachers' Approaches to Teaching Content. Journal of Agricultural Education, 57(4): 86-100. https://doi.org/10.5032/jae.2016.04086

Şimşek, N. \& Boz, N. (2016). Analysis of Pedagogical Content Knowledge Studies in the Context of Mathematics Education in Turkey: A Meta-Synthesis Study, 16(3):799-826. DOI 10.12738/estp.2016.3.0382

Sisman, G.T. \& Aksu, M. (2016). A Study on Sixth Grade Students' Misconceptions and Errors in Spatial Measurement: Length, Area, and Volume. International Journal of Science and Math Education, 14, 
1293-1319. doi: 10.1007/s10763-015-9642-5.

Tseng, J.J. (2016). Developing an Instrument for Assessing Technological Pedagogical Content Knowledge as Perceived by EFL Students. Computer Assisted Language Learning, 29:2, 302-315.

Widodo, A. 2017. Teacher Pedagogical Content Knowledge (PCK) and Students' Reasoning and Wellbeing. Journal of Physics: Conf, 812 (1):1-7.

Wong, T. K., \& Sulaiman, S. (2008). The Level of Alternative Framework among Form Five Science Stream Students on the Topic of Buoyancy. National Conference of Science and Mathematics Education, Johor, Malaysia.

Wooditch, A.M., Rice, A.H., Peake, J.B. \& Rubenstein, E.D.(2018). The Development of Preservice Agriculture Teachers' Pedagogical Content Knowledge through a Greenhouse for Teachers Course. Journal of Agricultural Education, 59(3): 1-14.

Zaman, R. \& Ahangari, S. (2016). Characteristics of an Effective English Language Teacher (EELT) as Perceived by Learners of English. International Journal of Foreign Language Teaching \& Research, 4(14):69-88. 